\title{
HALREV
}

Hasanuddin Law Review

\section{Legal Guarantees and Inconsistency of State Recognition to the Right of Religion/Belief in Indonesia}

\author{
Kadarudin \\ Doctoral Program, Faculty of Law, Hasanuddin University. \\ Jln. Perintis Kemerdekaan Km. 10, Tamalanrea, Makassar, South Sulawesi, 90245, Indonesia. \\ Tel./Fax: +62-411-585035 E-mail: kadarudin.alanshari@gmail.com
}

Submitted: Feb 6, 2015; Reviewed: Mar 19, 2015; Accepted: Apr 11, 2015

\begin{abstract}
The right to freedom of religion/belief has been guaranteed by law in Indonesia, but there are still going on some violations of the right to freedom of religion/belief in the various regions. The purpose of this study was to determine the form of the legal guarantee of the right to freedom of religion/belief in Indonesia, shape inconsistencies state recognition of the right to religion/belief in Indonesia, and efforts to improve the rights of religion/belief in Indonesia. This paper uses a normative study. It was found that there are some rules that apply in Indonesia, which may hinder the implementation of the right of religion/belief, thus causing the occurrence of cases of rights violations religion/belief in some areas, should therefore rules should be immediately revoked. The conclusions of this paper are contained inconsistent state recognition of the right to religion/ belief in Indonesia.
\end{abstract}

Keywords: Human Rights; Right of Religion/Belief; State Recognition

\begin{abstract}
Abstrak: Hak kebebasan beragama/berkeyakinan telah di jamin oleh hukum di Indonesia, namun masih saja terjadi beberapa pelanggaran terhadap hak kebebasan beragama/ berkeyakinan di berbagai daerah. Tujuan penelitian ini adalah untuk mengetahui bentuk jaminan hukum hak kebebasan beragama/ berkeyakinan di Indonesia, bentuk inkonsistensi pengakuan negara terhadap hak beragama/berkeyakinan di Indonesia, dan upaya untuk membenahi hak beragama/berkeyakinan di Indonesia. Tulisan ini menggunakan penelitian normatif. Hasil penelitian menunjukkan bahwa masih terdapat beberapa aturan yang berlaku di Indonesia yang dapat menghambat terlaksananya hak bergama/berkeyakinan, sehingga menyebabkan terjadinya kasus pelangaran hak beragama/berkeyakinan di beberapa daerah, oleh karena itu seharusnya aturan-aturan tersebut harus segera di cabut. Simpulan dari tulisan ini adalah terdapat inkonsistensi pengakuan negara terhadap hak beragama/berkeyakinan di Indonesia.
\end{abstract}

Kata Kunci: Hak Asasi Manusia; Hak Beragama/Berkeyakinan; Pengakuan Negara 


\section{INTRODUCTION}

The title of this article was inspired by the many cases of violations to freedom of religion/belief which is conducted by government (i.e., the central and local government) in relation to state recognition of religion/ belief. In addition, this paper is a continuation of the authors under the title "The Limitation of the Rights to Freedom of Religion and Belief in Indonesia's Forgotten", which is posted by the Indonesian Legal Resources Center (ILRC) in the Journal of Social Justice, Promoting Human Rights and Social Justice, in 2013 (but in a different angle).

Said rights ${ }^{1}$ is something that is inherent in every human being, and rights can be applied in every scope of life. But remember that in terms of its rights, every human being does not live alone because there are other humans. So do not someone violated rights of others in an attempt to obtain, maintain, or fulfill their human rights itself. While human rights are the rights possessed by every human being since man was born on earth until he died.

Human rights can be defined as something inherent in us as a human being, that if there is no such right is impossible we can live as a human being. The rights possessed by every human being because he was born as a human being, and not given by the people or the state. Human rights derived from God and is a right inherent and can not be underestimated.

1 Has the sense of "True: there are genuine; immense power to demand anything; authority; possession". Muhammad Ali. (without year). Kamus Lengkap Bahasa Indonesia Modern. Jakarta: Pustaka Amani. p.110
According to the Law Number 39 Year 1999 concerning Human Rights, set that:

Human rights are rights inherent to the human being as a creature of God that must be respected, upheld and protected by the state, law, government and everyone for the respect and protection of human dignity. ${ }^{2}$

In addition to compensate for the liberty, every human being has the ability to take responsibility for all actions he has done, and is also responsible for the result over the unwillingness to act/do something. The right is needed by every human rights but to protect themselves and the dignity of humanity, is also used as the foundation of morals and ethics in associating or dealing with other human beings.

In exercise their human rights, everyone is obliged to respect and appreciate the rights that are shared by others. Awareness of human rights, the dignity of humanity, starting from the man born in the world. It was caused by the human rights that have been around since man was born and is a natural right inherent in human beings, one of the natural rights is the right to freedom of religion/belief. These rights is one part of the civil and political rights of every human being.

According to the human rights theory, the state is obliged that: (1) "obligation to respect" refers to the duty of the state to discipline the whole apparatus from committing violations/intervention for the implementation of human rights (vertical aspect); (2) "obligation to protect" emphasis

2 Article 1 point 1 Law of the Republic of Indonesia Number 39 Year 1999 concerning Human Rights. 
on measures to face violations (human rights abuse) committed by certain parties (horizontal aspect). Obligation "to protect" is divided into two; obligation "to prevent" the occurrence of a crime/violation of human rights (human rights abuse); and the obligation "to correct" when a crime or human rights violations have occurred; and (3) " $o b$ ligation to fulfill" emphasizes the positive efforts the state through legislative mechanisms, judicial, or administrative measures to ensure the implementation of human rights in the most concrete level. ${ }^{3}$

In Indonesia, in accordance with the mandate of the Constitution, the right to freedom of religion/belief has been set in the Constitution of the Republic of Indonesia Year 1945 Section 28E and 28I, even regulated also in Article 22 of the Law of the Republic of Indonesia Number 39 of 1999 on Human Rights, and the Law of the Republic of Indonesia Number 12 Year 2005 on the Ratification of the International Covenant on Civil and Political Rights, but there is still happen several violations of the right to freedom of religion/belief in many areas. $^{4}$

3 Eide,Asbjorn. Catarina Krause and Allan Rosas (Eds). (2001). Economic, Social and Cultural Rights; A Textbook, Second Revised Edition. The Hague: Kluwer Law International. p.2325; See more Nowak, Manfred. (2005). "U.N. Covenant on Civil and Political Rights; CCPR Commentary", 2nd revised edition. N.P. Engel, Publisher. p.XX-XXI. And see more KontraS. (2012). Laporan Pemantauan Pemolisian Dan Hak Atas Berkeyakinan, Beragama, Dan Beribadah (Jemaah Ahmadiyah Indonesia Di Manis Lor, Ciputat, Cikeusik, \& Jemaat Kristen HKBP Ciketing Dan GKI Taman Yaskin). Jakarta: KontraS. p.3-4.

4 Case of rejection of Family Card Marapu religious communities in the region of East Sumba, East Nusa Tenggara by the local government. Even their children (Marapu
Based on Article 8 of the Law of the Republic of Indonesia Number 39 of 1999 on Human Rights, that "Protection, Promotion, Enforcement, and fulfillment of human rights ${ }^{5}$ is primarily the responsibility of go vernment". But there is inconsistency of state recognition to the right of religion/belief in Indonesia (especially in regions), so that the need for a further study related to the issue of the right to freedom of religion/ belief in Indonesia.

The issue to be discussed in this paper is what kind of legal guarantees the right to freedom of religion/belief in Indonesia? What kind of inconsistency of state recognition to the right of religion/belief in Indonesia? And how efforts to improve the rights of religion/belief in Indonesia? The purpose of this research is to know and understand the shape of the legal guarantees the right to freedom of religion/belief in Indonesia, inconsistencies form state recognition to the right of religion/belief in Indonesia, and an attempt to improve the rights of religion/ belief in Indonesia.

religious communities) are not given a birth certificate, Available from: (http://indonesia. ucanews. com/2014/03/19/penganut-marapuberjuang-agar-kepercayaan-mereka-diakui/). Other cases of violation of religions "Baha'i" is believed by the public Blitar in East Java, but not put on the column of religion on identity card (KTP), See: (http://nasional. news.viva. co.id/news/read/524617-soal-agama-baha-i-mendagri-tunggu-keputusan-kemenag)

5 Including the rights of (1) Everyone is free to believe in their own religion and to worship according to his religion and beliefs. And (2) The state guarantees the freedom of every person to believe their own religion and to worship according to his religion or belief, as stipulated in Article 22 of the Law of the Republic of Indonesia Number 39 of 1999 on Human Rights. 


\section{METHODS}

This type of research in this paper is a normative legal research, ${ }^{6}$ reviewing the rule of law concept, legal theory, and legal materials relating to the issues to be discussed. This research was conducted at the office of Indonesian Legal Resource Centre (ILRC) Jakarta, and in the Office of Legal Aid and Consultancy Unit of the Faculty of Law, Hasanuddin University (UKBH FH-UH), Makassar, Indonesia. The approach used in this study is the statute approach ${ }^{7}$ and conceptual approach. ${ }^{8}$

In a normative legal research, the source of the data used are of legal materials, which consist of Primary law materials are materials that have the binding force of law, which some national and international legal instruments include laws, court decisions, a joint decree, the rules together, international covenants and declarations related to this article. Secondary law materials are materials that gives an explanation of the primary legal materials, including books and journals legal research. Tertiary law materials are materials that gives an explanation of primary law materials and secondary law materials, including legal dictionaries and encyclopedias that are related to this article.

Data collection techniques in this research conducted by the library research, ${ }^{10}$

6 Soerjono Soekanto and Sri Mamudji. (2011). Penelitian Hukum Normatif. Jakarta: Rajawali Pers, p. 14

7 Peter Mahmud Marzuki. (2010). Penelitian Hukum. Jakarta: Kencana Prenada Media Group, p. 96

$8 \quad$ Ibid. p. 137

9 Salim HS. and Erlies Septiana Nurbani. (2013). Penerapan Teori Hukum Pada Penelitian Tesis dan Disertasi. Jakarta: Rajawali Pers, p. 16

10 See more about the research literature in the that studies and investigates some of the provisions of national and international law, textbooks, dictionaries law, legal journals which are considered relevant to this paper. Data were collected, then processed and analyzed using qualitative data analysis, are in narrative form and not the form of numbers, ${ }^{11}$ then presented descriptively ${ }^{12}$.

\section{ANALYSIS AND DISCUSSION}

The Legal Guarantees the Right to Freedom of Religion/Belief ${ }^{13}$

The right to freedom of religion/belief has been arranged through a written instrument, both in the international and national levels Indonesia, because the right to freedom of religion/belief comes to human rights. The right to freedom of religion/belief has been recognized through various provisions of the principal international human rights instruments, as one part of the rights that are important.

In general, the right to freedom of religion/belief contained in the Universal Declaration of Human Rights (UDHR) ${ }^{14}$

book by Gorys Keraf. (2004). Komposisi. Nusa Tenggara Timur: Nusa Indah, p. 187

11 B. Miles, Matthew and A. Michael Huberman. (2009). Analisis Data Kualitatif, Buku Sumber Tentang Metode-Metode Baru, Translated: Tjetjep Rohendi Rohidi. Jakarta: UI Press, p. 15

12 Soerjono Soekanto. (2012). Pengantar Penelitian Hukum. Jakarta: UI-Press, p.9

13 Kadarudin. "Pembatasan Hak Kebebasan Beragama dan Berkeyakinan di Indonesia yang Terlupakan", Jurnal Keadilan Sosial, 3(1): 25-30

14 Universal Declaration of Human Rights is the first definitive statement about 'human rights' and which states clearly the rights that are universal. This document is an international agreement signed by the parties (countries) that are members of the United Nations. However, the agreement is not legally binding and do not provide the protection that can 
or more commonly known in Indonesia as Deklarasi Umum Hak Asasi Manusia (DUHAM) and set out in the International Covenant on Civil and Political Rights (ICCPR). Both are the main pillars of the principal international human rights instruments (international bill of human rights), besides the International Covenant on Economic, Social, and Cultural Rights (ICESCR). However, the implementation of an autonomous rights as they are less implemented.

In general UDHR/DUHAM announced in 1948 contains four basic rights. First, individual rights or the rights of every person. Second, collective rights or the rights of communities that can only be enjoyed with others, such as the right to peace, the right to development and the right to a clean environment. Third, civil and political rights, which shall include the rights that already exist in the laws and regulations in Indonesia, such as: the right to self-determination, the right to obtain redress for those whose freedoms have been violated; the right to life, the right to freedom of thought, conscience and religion, equal rights for women and men to enjoy civil and political rights, a right to be told the reasons at the time of arrest, equality of rights and responsibilities between spouses, the right to freedom of expression. Fourth, the economic, social and cultural rights, among others, the right to enjoy freedom from fear and poverty; the prohibition on discrimination of race, skin

be imposed. See Siti Musdah Mulia. Hak Asasi Manusia dan Kebebasan Beragama. (Paper). Available from: http://www.elsam. or.id/downloads/1363164069_HAM dan Kebebasan_Beragama.Musdah_Mulia.pdf [Accessed August 6, 2014]. color, sex, gender, and religion, equality between men and women to enjoy economic, social and cultural; the right to get a job; the right to receive fair wages for workers male and female; the right to form trade unions; the right to strike; the right to education: the right to be free from hunger.

The right to freedom of religion/belief in the international human rights document normatively regulated in Article 18 UDHR, is:
Everyone has the right to freedom of thought, conscience and religion; this right includes freedom to change his religion or belief, and freedom, either alone or in community with others and in public or private, to manifest his religion or belief in teaching, practice, worship and observance.

UDHR called the term basic human rights, ${ }^{15}$ human rights are the most fundamental and categorized as the most important rights to be prioritized in the various laws and policies, both at national and international levels. Basic human rights are a set of rights that ensure the needs of primary material and non-material human beings in order to realize the full human existence, which is a valuable human and dignified. Although, explicitly not found a statute or explanation detailing what rights are included in the basic human rights, however, generally can be mentioned the

15 Ibid. p.2; the first Paragraf in UDHR declare: "whereas recognition of the inherent dignity and of the equal and inalienable rights of all members of the human family is the foundation of freedom, justice and peace in the word". See more Gunawan Sumodiningrat and Ibnu Purna (ed). (2004). Landasan Hukum dan Rencana Aksi Nasional HAM di Indonesia 2004-2009. Jakarta. p.9 
basic rights include the right to life, the right to food, medical care, freedom from torture, and freedom of religion. ${ }^{16}$

Basic rights as a whole based on one fundamental principle, namely the appreciation and respect for human dignity. ${ }^{17}$ Right to religious freedom is classified in the category as one of the basic human rights, is absolute and are in internum forum which is a manifestation of inner freedom (freedom to be). It is classified as a non-derogable rights. ${ }^{18}$ It mean, the rights that are specifically expressed in human rights treaties as a right that can not be deferred fulfillment by the state in any circumstances, including during a state of emergency, such as civil war or military invasion. Non-derogable Rights is seen as the most important right of human rights. ${ }^{19}$ Non-derogable rights should be implemented and respected by the state parties of the international covenants under any circumstances and in situations which nevertheless.

The right to freedom of religion/belief is expressed also in more detail in International Covenant on Civil and Political Rights, particularly in the Article 18. This Covenant has been ratified by the Government of Indonesia through the Law Number 12 Year 2005 concerning the ratification of

6 See Siti Musdah Mulia, Ibid. p.3

17 Ibid.

18 Article 4 (2) ICCPR mentions: No derogation from articles 6,7,8 (paragraphs 1 and 2), $11,15,16$ and 18 may be made under this provision. See Siti Musdah Mulia, Ibid.

19 Ibid. For this explanation, among others, can be seen Groome, Dermot. (2001). The Handbook of Human Rights Investigation: A comprehensive guide to the investigation and documentation of violent human rights abuses. Massachusetts: Human Rights Press, p. 6 the Covenant on Civil and Political Rights, which provides that:

(1) Everyone shall have the right to freedom of thought, conscience and religion. This right shall include freedom to have or to adopt a religion or belief of his choice, and freedom, either individually or in community with others and in public or private, to manifest his religion or belief in worship, observance, practice and teaching.

(2) No one shall be subject to coercion which would impair his freedom to have or to adopt a religion or belief of his choice.

(3) Freedom to manifest one's religion or beliefs may be subject only to such limitations as are prescribed by law and are necessary to protect public safety, order, health, or morals or the fundamental rights and freedoms of others.

(4) The States Parties to the present Covenant undertake to have respect for the liberty of parents and, when applicable, legal guardians to ensure the religious and moral education of their children in conformity with their own convictions.

In addition to the ICCPR, the right to freedom of religion/belief is also stipulated in the International Convention on the Elimination of all forms of Racial Discrimination/ ICERD (ratified the Law of the Republic of Indonesia Number 29 Year 1999); International Convention on the Elimination of all forms of Discrimination Against Women/ CEDAW (ratified the Law of the Republic of Indonesia Number 7 Year 1984); Convention against Torture and Degrading Treatment or Punishment Other Cruel, Inhuman, and Degrading Man/CAT (ratified the Law of the Republic of Indonesia Number 5 Year 1998); and Convention on the Rights of the Child/CRC (ratified by Decree of the President of the Republic of Indonesia Number 36 Year 1990). 
Groome explained, freedom is the power or ability to act without coercion; the absence of barriers or obstacles; the power to choose. Furthermore Groome gave basic freedoms into two categories, namely the rights and personal protection; and the rights and protections in the justice system. Rights groups and personal protection include: freedom of religion; freedom of thought; freedom of expression; freedom of the press; freedom of association; freedom of movement; the right to private life; the right to assemble; the right to organize; the right to education; and the right to participate in government. From here came to be known term four free$d o m^{20}$ by F.D. Roosevelt, called: freedom of expression, freedom of religion, freedom of desire and freedom of feeling fear.

Meanwhile, according to Robert P. George belief is "in its fullest sense, religion is the human person's being in right relation to the divine the more than merely human source or sources, if there be such, of meaning and value", ${ }^{21}$ The essence to freedom of religion/belief is covered in eight

20 See Siti Musdah Mulia, Ibid. p.5; The fourth form of freedom is derived from the contents of Franklin Delano Roosevelt speech, in January 1941, in which he said that the existence of peace in the world is associated with the four essential freedoms. This freedom includes 'freedom of expression'; freedom of workship; freedom from want (in this case is the certainty or economic security); freedom from fear (arms reduction). The speech went on to become a key document in order to form the United Nations (UN) and provide the protection and promotion of human rights. The speech was delivered before the US was involved in World War II. See Conde, H. Victor. (1999). A Handbook of International Human Rights Terminology. Lincoln \& London: University of Nebraska Press, p.47.

21 P. George, Robert. "Religious liberty and the human good", International Journal for Religious Freedom, 5(1): p.38 major components, as follows:

1. Internal Freedom: Everyone has freedom of thought, conscience and religion. This right shall include freedom to have or adopt a religion or belief of his choice, including for religious conversion and beliefs.

2. Eksternal Freedom: Everyone has the freedom, whether individually or in community, in public or private to manifest his religion or belief in teaching, and of worship.

3. Not coercion: Nobody can be subject to coercion which would reduce his freedom to have or adopt a religion or belief choice.

4. Not discrimination: The State is obliged to respect and guarantee freedom of religion or belief of all individuals within its territory without distinction as to race, color, sex, language, religion and belief, or political opinion, inhabitants: native or newcomer, as well as the origin he suggested.

5. The rights of Parents and Guardians: The State is obliged to respect the freedom of parents and legal guardians, if there is to ensure that the religious and moral education for their children in accordance with their own convictions.

6. Freedom Institutions and Legal Status: vital aspect of freedom of religion or belief for a religious community or association is to organize as a community. Therefore, religious communities have freedom of religion or belief includes the right of independence in organizational arrangements.

7. The limitation allowed on External freedom: freedom to run one's religion or belief may only be restricted by law, and even then solely in the interest of protecting public safety and order, public health or morals, and in order to protect the rights and the freedom of others.

8. Non-Derogability: The State must not reduce the freedom of religion or belief in any circumstances and for any reason. ${ }^{22}$

22 See Siti Musdah Mulia, Loc.Cit. An explanation of this is explicitly found in ICCPR Article 18 paragraph (1); ECHR Article 9 paragraph (2); dan ACHR Article 12 paragraph (3). 
While at the level of Indonesian law generally governs the right to freedom of religion/belief in the Pancasila and the various levels of legislation. Therefore, the right to freedom of religion/belief is expressly protected and guaranteed by the laws of Indonesia, both in terms of confidence and implementation of such beliefs (worship). However, it can be said that in Indonesia, both concerning legislation, the state apparatus to carry and run it as well as citizens who become important pillars is a long process, not a one-off. Become Indonesia, after the proclamation, is not a final product that is ready to use without any long process to make it happen.

Pancasila as the state philosophy (philosophische grondslag) has guided its citizens to religious (point 1), by upholding humanitarianism (point 2) and unity (point $3)$. The problems facing the nation settled by deliberation (point 4), not by the logic of the majority. Rich and poor without extreme social inequality (point 5). Indonesia wishes at once rooted in collectivism individualism, different from the American desire rooted in invidualisme. Pancasila is not welfare invidual idealism, but fairly prosperous society. Social justice is the estuary of the four point other. ${ }^{23}$

23 M. Amin Abdullah, Kebebasan Beragama Atau Berkeyakinan Dalam Perspektif Kemanusiaan Universal, Agama-Agama Dan Keindonesiaan (Makalah Disampaikan dalan forum Pelatihan Lanjut Hak Asasi Manusia bagi Dosen Pengajar Hukum dan HAM oleh Pusat Studi Hak Asasi Manusia Universitas Islam Indonesia (PUSHAM UII) Yogyakarta bekerjasama dengan Norwegian Centre for Human Rights (NCHR) University of Oslo Norway, Djogjakarta Plaza Hotel, tanggal 10 Juni 2011), p.14-15
Article 28E Constitution of the Republic of Indonesia Year 1945, which provides that:

Everyone is free to believe in religion and to worship according to their religion, to choose education and teaching, citizenship, choosing a place to stay in the territory of the country and left it, as well as the right to return (paragraph 1); everyone is entitled to freedom of belief to believe, express thoughts and attitudes, in accordance with his conscience (paragraph 2). ${ }^{24}$

In addition referring to Article $28 \mathrm{E}$ in terms to the right of freedom of religion/ belief in Indonesia, the Constitution of the Republic of Indonesia Year 1945 reordered in Article 28I, which stipulates that:

The right to life, freedom from torture, freedom of thought and conscience, freedom of religion, the right not to be enslaved, the right to recognition as a person before the law, and the right not to be prosecuted based on retroactive law is a human right that is not can be reduced under any circumstances.

As a member state of the United Nations (UN) and has ratified the law declared by the world body, the state authorities are obliged to fulfill its obligations under various international instruments that have been ratified by the Dewan Perwakilan Rakyat Republik Indonesia (DPR RI). Several instruments have been ratified by, among others, the Universal Declaration of Human Rights (UDHR), Declaration on the Elimination of All Forms of Intolerance and of Discrimination Based on Religion or Belief (DEAFIDBRB), The International Covenant on Civil and Political Rights (ICCPR), International

24 The second change of UUD RI 1945, See Majelis Permusyawaratan Rakyat. (2012). Undang-Undang Dasar Negara Republik Indonesia Tahun 1945. Jakarta: Sekretariat Jenderal MPR RI. p.158 
Covenant on the Rights of Economic, Social, and Cultural (ICESCR). International Convention on the Elimination of All Forms of Racial Discrimination (ICERD), International Convention on the Elimination of All Forms of Discrimination Against Women (CEDAW), Convention against Torture and Degrading Treatment or Punishment Other Cruel, Inhuman, and Degrading Man (CAT), and Convention on the Rights of the Child (CRC). In addition, the state authorities are also obliged to ensure, maintain, protect and promote human rights as set out in the Law of the Republic of Indonesia Number 39 Year 1999 on Human Rights. ${ }^{25}$

The rules concerning the right to freedom of religion/belief, there are also some other rules which, according to the author can restrict the freedom of religion/ belief in Indonesia. Some of these rules are Law Number 1/PNPS/1965 on the Prevention of Abuse and/or blasphemy. ${ }^{26}$ What is known in Indonesia as the SKB (Surat Keputusan Bersama). The SKB made by 3 ministers,

25 M. Amin Abdullah, Op.Cit., p.14-15

26 Ibid. p.17; Mentioned in the Report of the Implementation of the Convention on the Elimination of All Forms of Racial Discrimination (ICERD) in Indonesia, that one of the causes of "disappearance" of 517 religious denominations from 1949 to 1992 is UU No. 1/ PNPS/1965. Yet according to Article 27 of the International Covenant on Civil and Political Rights, minorities shall not be denied the right to profess and practice their own religion. Religion and belief is an essential part of the identity of an ethnic group and context can not be separated from the issue of the protection to freedom of religion or belief. See Colbran, Nicola. Kebebasan Beragama atau Berkeyakinan di Indonesia: Jaminan secara Normatif dan Pelaksanaannya dalam Kehidupan Berbangsa dan Bernegara, in Lindholm, Tore, et.al. (ed.). (2004). Facilitating Freedom of Religion or Belief: A Deskbook. Leiden: Martinus Hijhoff Publishers. namely the Minister of Religious Affairs, General Attorney, and Ministry of Internal Affairs of the Republik of Indonesia Number: 3 Year 2008; Number: KEP-033/A/JA/6/2008; Number 199 Year 2008 on Warning and Command To adherents, members, and/or Board Member Jemaat Ahmadiyah Indonesia (JAI) and Public Citizen. ${ }^{27}$

The SKB, also known as Surat Peraturan Bersama (SPB) are made by the Minister of Religious Affairs and the Minister of Internal Affairs Number 8/9 Year 2006 on Guidelines Task Regional Head/Deputy Head In Maintenance of Religious Harmony, Empowerment Forum Kerukunan Umat Beragama (FKUB), and the Construction of Houses of Worship, then at the local level there is Regulation, both provincial and districts/cities regulations, and even regulation or decree of the

27 M. Amin Abdullah, Ibid. The annual report on Religious Life in Indonesia in 2008, reported that the violence experienced by Ahmadiyah before and after the issuance of SKB on Jemaat Ahmadiyah Indonesia (JAI) in 2008, there were 10 cases of violence against the Ahmadiyah lasted like invasion, destruction, burning, and sealing against the mosque and the assets of Ahmadiyah in different places. Violence against Ahmadis intensified so, in 2011, in particular, known as events Cikeusik, Pandeglang, Banten, West Java. See Suhadi Cholil, dkk. (2010). Laporan Tahunan Kehidupan Beragama di Indonesia 2009, Bagian Dua (Yogyakarta: Center for Religious and Cross Cultural Studies, Universitas Gajahmada. P.42, and until recently listed 20 heads of regional policies related to ban Ahmadiyah, See more Siti Aminah. (2011). Kasus Ahmadiyah Dalam Perspektif Keadilan Sosial, Jurnal Keadilan Sosial, Mempromosikan Hak Asasi Manusia dan Keadilan Sosial, 2(1): p.52; compare with Nurul Mahmudah. (2010). Menyoal Tanggungjawab Negara Dalam Menjamin Kebebasan Beragama Berkeyakinan, Mitra Hukum Kebebasan Beragama/Berkeyakinan, 1(1): p.14 
Governor/Regent. ${ }^{28}$

Inconsistency Form of the State Recognition to the Rights of Religion/Belief

Human rights talks with the legal approach, the focus is on concrete, if someone is violating human rights or not. Indicators used as a parameter here, is normative. Therefore, the measuring instrument is legal instruments, both nationally and internationally. In this context, the discussion of human rights was also carried out with the focus of discussion on instruments and institutions used, and what mechanisms are taken to uphold human rights. Here, the role of the state is very strong, because the standard of judgment about a person's true or not, made by the state through legislation. In fact, it is the state that determines whether the standard has been violated. Furthermore, the process for determining whether one or violates by someone, everything is done through the mechanism of state institutions, such as courts. ${ }^{29}$ in violation of resolution mechanisms both.

The difference between the implementation of economic, social and cultural rights and civil and political rights are in violation

28 For example: Banjarmasin District Regulation Number 5 Year 2004 on Ramadhan, Regent Dompu Decree Number Kd.19./ HM.00/527/2004, Mei 8, 2004 on Liability Reading the Al-Qur'an by all PNS and the guests meet Regent, Regent warrant Banjarmasin Number 065.2/00023/ORG about the use of Hijab For Women PNS in the Government of the District of Banjarmasin, dated January 12, 2004, Bengkulu Mayor Instruction Number 3 Year 2004 on Program Activity Increasing Faith, Sukabumi Regent Instruction Number 4 Year 2004 on the use of Muslim Clothing For Students and University Students in Sukabumi.

29 Hamid Awaludin. (2012). HAM, Politik, Hukum, dan Kemunafikan Internasional. Jakarta: Kompas, p. 58 of both resolution mechanisms. The civil and political rights are often said to be negative rights, which the Government is required to refrain from intervening too far into its rights, but if there is a breach in the implementation and fulfillment it could take legal mechanisms and report to the court either by individuals or groups. While the economic, social and cultural rights often referred to as positive rights, that the Government is required to intervene in the exercise of these rights in order to realize the fulfillment of these economic, social and cultural rights, but in case of violation, could not report to the court for the charges of violations and therefore this right is often seen as non justiciable rights. Judging from the two forms of classification above rights, the right to freedom of religion/belief is one part of civil and political rights.

"Everybody is equal before the law," but the fact is different. ${ }^{30}$ The lack of Indonesian government's role in protecting citizens without discrimination ${ }^{31}$ the set difference of religion, belief, race, language, and social status as the fulfillment of human rights obligations in providing, primarily related to the recognition of the state of some belief ancestors they have believed for generations, as has been pointed out in the background of the author that there are cases in his starting a family card and not given birth certificates

30 Soetandyo Wignjosoebroto. "Rule of Law; Suatu Perbincangan di Seputar Masalah Kesamaan Akses untuk Memperoleh Keadilan Khususnya yang Menyangkut Kepentingan Kaum Miskin", Jurnal Keadilan Sosial, 1(1): 6

31 See explanation of discrimination in Fulthoni, et.al. (2009). Memahami Diskriminasi, Buku Saku Untuk kebebasan Beragama. Jakarta: ILRC, p.3 
for children of Marapu community in the East Sumba, East Nusa Tenggara by local government, besides cases of omission on the column of religion on identity cards cult "Baha'i" community believe that in Blitar in East Java. From some of these cases, inconsistency of state recognition can be seen from the 3 (three) indicators set in the human rights and can not be met by the government, there is respect, protect, and fulfill,,$^{32}$ as the author described below:

\section{The state's obligation to respect}

In terms of the state's obligation to respect, it refers to the duty of the state to respect the right to freedom of religion and belief are believed to by citizens. The failure of the entire country for disciplining officers from committing violations/intervention on the implementation of human rights (vertical aspect). ${ }^{33}$ Seen from this obligation, it appears the Government of Indonesia (in this case the president) did not fulfill their obligation to respect the implementation of the human rights of its citizens. President is unable to discipline the entire apparatus to not commit offense/intervention on the implementation of the human rights of its citizens.

This can be evidenced by the case of rejection of the family card and not given birth certificates for children of the belief Marapu community in the East Sumba, East Nusa Tenggara by local government, besides cases of omission on the column of

32 Compare with Abdul Maasba Magassing, et.al. (2014). Kompilasi Hasil Penelitian Putusan Pengadilan dan Kebijakan Daerah Terkait Hak-Hak atas Kebebasan Beragama/Berkeyakinan. Jakarta: ILRC, p.200-210

33 Eide, Asbjorn. Op.Cit., p.23-25 religion on identity cards religion "Baha'i" community believe that in Blitar in East Java.

The government plays an important role for the preservation of the unity and harmony in the nation, state, and society. The resulting policies will affect the fulfillment of the rights of every citizen, including to freedom of religion and belief..$^{34}$ In addition, the government should not discriminate in carrying out its human rights obligations, as just different beliefs, or refusal of a group of people over another group beliefs, so that countries take actions that can harm and violate the rights of a group of people to the belief that he believed (although the conviction was rejected by the other group). Such as the case of rejection of the family card and not given birth certificates for children of the belief Marapu community in the East Sumba, East Nusa Tenggara by local government.

More than that, the case was not included in the column of religion on identity cards religious sects "Baha' $i$ " which is believed by the public in Blitar in East Java. The government should be more objective in providing the fulfillment of human rights of its citizens, so long as a group of people who have confidence then the conviction was rejected by another group, still as a citizen of Indonesia.

The state in this regard the Government of Indonesia is obliged to respect belief that a group of people as a human rights of its citizens, and as one of its obligation to

34 See, Uli Parulian Sihombing, et.al. (2012). Ketidakadilan dalam Beriman, Hasil Monitoring Kasus-Kasus Penodaan Agama dan Ujaran Kebencian atas Dasar Agama di Indonesia. Jakarta: ILRC, p. 92 
provide the fulfillment of human rights to its citizens without having to consider the rejection of the beliefs of a group of people that.

According to Thomas Schirrmacher of research results stated that:

The Indonesian fatwa council, Majelis Ulama Indonesia (Indonesian Council of Ulema) or MUI, plays a disastrous role since its fatwas directed against religious minorities are actually not legally binding and yet are increasingly used by the government and cast into law. ${ }^{35}$

\section{The state's obligation to protect}

In terms of the state's obligation to protect, this emphasis on the steps facing violation (human rights abuse) performed by certain parties (horizontal aspect). Obligation "to protect" is divided into two; obligation "to prevent" the occurrence of a crime/human rights abuse; and the obligation "to correct" when a crime or human rights abuse have occurred. ${ }^{36}$ Seen from this obligation, it appears the government had committed a violation of the right to belief Marapu adherents, and Baha'is based on her faith hereditary, the rejection of the family card, it serves no birth certificate, and not in their belief cantumkannya (Baha'i) in the column of religion on identity cards.

The government does not take action to correct its agents (in this case the Ministry Internal Affairs, the authorities concerned family card, identity cards, and birth certificates) when it refused to serve the maintenance of a birth certificate, to include beliefs (Baha'i) in the column of religion on identity cards, as well as the rejection of the family

\footnotetext{
35 Schirrmacher, Thomas. "Religious freedom in Indonesia," International Journal for Religious Freedom, 6(1/2): p.90

36 Eide, Asbjorn. Op.Cit., p.23-25
}

that owned the card, even though they had dozens of times they (believers Marapu, and Baha'is) protest, but until now has not received attention by the central government and local government.

\section{The state's obligation to fulfill}

In terms of the state's obligation to fulfill, this emphasis on positive efforts through legislative mechanisms, judicial, or administrative to ensure the implementation of human rights in the most concrete level. ${ }^{37}$ From this obligation, looks Indonesia in this case both the central government and the local government is not doing positive efforts through the mechanism of the legislative, judicial, or administrative order to ensure the implementation of the human rights of its citizens concerning the right to freedom of religion/ belief. This can be evidenced by the many rules are made about human rights, but is not run by the government.

For example in the case of rejection of the family card, it serves no birth certificate, and the exclusion of their belief in the identity. Though clearly the Constitution of the Republic of Indonesia Year 1945 Article $28 \mathrm{E}$ and 28I, even regulated also in Article 22 of the Law No. 39 Year 1999 concerning Human Rights, and the Law No. 12 Year 2005 concerning the Ratification of the International Covenant on Civil and Political Rights. All of which regulates the right to freedom of religion/belief for everyone because it is part of their human rights, but then the government is not consistent in implementing the rules, even the Law Number 1/PNPS Year 1965 which is contrary to the

\footnotetext{
37 Ibid.
} 
Constitution as the highest law to date has not revoked, ${ }^{38}$ and is still used as the main indicator for the government to justify and acknowledge the religion/belief community as a religion/belief legitimate.

\section{Efforts to Improve the Rights of Religion/} Belief in Indonesia.

General Comment Number 22 of the ICCPR further explain the fact that a religion is recognized as the state religion, or religion was declared as the official religion or tradition, or religion consists of a majority of the population, should not lead to nonenjoyment of the rights guaranteed by the Covenant, including by Article 18 and Article 27 of the ICCPR, and led to discrimination against other religions or those who are not religious or belief. ${ }^{39}$

In the execution of its responsibilities, the state is allowed to restrict certain rights on the basis of some limitation clause. Freedom of religion and belief, including the non-derogable rights, so it can not be reduced. However, not all aspects of the rights and freedom of religion and belief are within

38 It is true that this law has judicial review by the Constitutional Court by Decision Number: 140/PUU-VII/2009, even the judges of the Constitutional Court also considered (in consideration 3.71) that the need for revision of the Law on Prevention blasphemy, both within the formal legislation and in substance that has elements of material that is clarified so as to avoid misinterpretation in practice. However, since the Court has no authority to make improvements editorial and contents coverage, but should only be declared constitutional or unconstitutional, then considering the substance of the law on Prevention of blasphemy as a whole is constitutional, the Court can not cancel or change editorial. Therefore, to fix it in order to be perfect, the authority of the legislators to do it through the legislative process. 39 Ibid. the rights that can not be reduced under any circumstances (non-derogable rights). The Constitution of the Republic of Indonesia especially in Article 28A, the following International Covenant on Civil and Political Rights Article 18 paragraph (3) stated that internum forum on this matter should not be limited without exception, while the region 'run' or the manifestation of the rights and freedom of religion and belief (externum forum) can be limited.

Once again, the state as a sovereign entity can limit only in the realm of manifestation, more precisely the scope of the externum forum. Restrictions and also intervene was formed in a legislation as a public norm that allows the public (people) to participate in shaping and overseeing its implementation, which is done by keeping also meet the principle of necessity and proportionality. ${ }^{40}$

Therefore, according to the author, in the case of rejection of the family card and not given birth certificates for children of the belief Marapu community in the East Sumba, East Nusa Tenggara by the local government, and the case is not posted on the religion column in the identity card "Baha' $i$ " which is believed by the public Blitar in East Java by the local government can not be justified. Though faith is a religion/ belief native Indonesia that had existed before Islam, Catholicism, Protestantism, Hinduism, Buddhism, and Confucianism into Indonesia.

The rejection of belief system that is not a religion, because the definition of religion that requires the fulfillment of several things,

40 Ibid. 
which have a holy book, have a prophet, believe in God, international recognition, and has a ritual. That is something very wrong as opposed to the internum forum of someone in relation to freedom of religion/ belief.

It is clear that, to minimize violations of freedom of religion/belief in Indonesia, then it being understood Law Number 1/ PNPS Year 1965 and some other related rules immediately revoked. It can no longer be used as a reference for the government to legalize religion/belief/faith which should be included in the identity card and family card, and who may obtain a birth certificate. More than that, its meaning that there is no more conflict between the regulations in Indonesia can even harmonizing national legislation with international regulations related to human rights that has already existed.

\section{CONCLUSIONS}

Inconsistency state recognition of the confidence of their fellow citizens in some areas make the adherents of the disappointed. According to the case of rejection of the family card and not given birth certificates for children of the belief Marapu community in the East Sumba, East Nusa Tenggara by the local government, and the case is not posted on the religion column in the identity card "Baha'i" which is believed by the public Blitar in East Java by the local government a few blurry portrait rights to freedom of religion/belief in Indonesia, which is famous for its respect for human rights.

Therefore, it is his government should strive for rights issue of religion/belief can be addressed in this country, one of them with the repeal rules be an obstacle to the creation of state recognition of any religion in the flow of its citizens believe.

\section{ACKNOWLEDGMENT}

Thank you for Uli Parulian Sihombing, S.H., LL.M., and Siti Aminah Tardi, S.H., which has much to contribute, especially given that the literature of this article can be completed.

\section{BIBLIOGRAPHY}

\section{Books:}

Abdul Maasba Magassing, et.al. (2014). Kompilasi Hasil Penelitian Putusan Pengadilan dan Kebijakan Daerah Terkait Hak-Hak atas Kebebasan Beragama/Berkeyakinan. Jakarta: ILRC.

Conde, H. Victor. (1999). A Handbook of International Human Rights Terminology. Lincoln \& London: University of Nebraska Press.

Eide, Absjorn. (2001). Catarina Krause and Allan Rosas (Eds), Economic, Social and Cultural Rights; A Textbook, Second Revised Edition. The Hague: Kluwer Law International.

Fulthoni, et.al. (2009). Memahami Diskriminasi, Buku Saku untuk Kebebasan Beragama. Jakarta: ILRC.

Gorys Keraf. (2004). Komposisi. Nusa Tenggara Timur: Nusa Indah.

Groome, Dermot. (2001). The Handbook of Human Rights Investigation: A comprehensive guide to the investigation and documentation of violent human rights abuses. Northborough. Massachusetts: Human Rights Press.

Gunawan Sumodiningrat and Ibnu Purna (ed). (2004). Landasan Hukum dan Rencana Aksi Nasional HAM di Indonesia 2004-2009. Jakarta.

Hamid Awaludin. (2012). HAM, Politik, Hukum, \& Kemunafikan Internasional. Jakarta: Kompas.

KontraS. (2012). Laporan Pemantauan Pemolisian dan Hak Atas Berkeyakinan, 
Beragama, dan Beribadah (Jemaah Ahmadiyah Indonesia Di Manis Lor, Ciputat, Cikeusik, \& Jemaat Kristen HKBP Ciketing Dan GKI Taman Yaskin). Jakarta: KontraS.

Lindholm, Tore et.al. (ed.). (2004). Facilitating Freedom of Religion or Belief: A Deskbook. Leiden: Martinus Hijhoff Publishers. . (2010). Kebebasan Beragama atau Berkeyakinan: Seberapa Jauh?: Sebuah Referensi tentang Prinsip-Prinsip dan Praktek. Yogyakarta: Kanisius.

Majelis Permusyawaratan Rakyat. (2012). Undang-Undang Dasar Negara Republik Indonesia Tahun 1945. Jakarta: Sekretariat Jenderal MPR RI.

Miles, Matthew B. and A. Michael Huberman. (2009). Analisis Data Kualitatif, Buku Sumber Tentang Metode-Metode Baru. Alih bahasa oleh Tjetjep Rohendi Rohidi. Jakarta: UI-Press.

Nowak, Manfred. (2005). "U.N. Covenant on Civil and Political Rights; CCPR Commentary", $2^{\text {nd }}$ revised edition. Oxford: N.P. Engel, Publisher.

Peter Mahmud Marzuki. (2010). Penelitian Hukum. Jakarta: Kencana Prenada Media Group.

Salim HS dan Erlies Septiana Nurbani. (2013). Penerapan Teori Hukum Pada Penelitian Tesis dan Disertasi. Jakarta: Rajawali Pers.

Soerjono Soekanto. (2012). Pengantar Penelitian Hukum. Jakarta: UI-Press. dan Sri Mamudji, 2011, Penelitian Hukum Normatif, Jakarta: Rajawali Pers.

Suhadi Cholil, dkk. (2010). Laporan Tahunan Kehidupan Beragama di Indonesia 2009, Bagian Dua, Yogyakarta: Center for Religious \& Cross Cultural Studies, Gadjah Mada University.

Uli Parulian Sihombing, et.al. (2012). Ketidakadilan dalam Beriman, Hasil Monitoring Kasus-Kasus Penodaan Agama dan Ujaran Kebencian atas
Dasar Agama di Indonesia. Jakarta: ILRC.

\section{Journals:}

George, Robert P. (2012). "Religious liberty and the human good", International Journal for Religious Freedom, 5(1): 38.

Kadarudin. (2013). "Pembatasan Hak Kebebasan Beragama dan Berkeyakinan di Indonesia yang Terlupakan", Jurnal Keadilan Sosial, 3(1): 25-30.

Nurul Mahmudah. (2010). "Menyoal Tanggung Jawab Negara dalam Menjamin Kebebasan Beragama Berkeyakinan", Mitra Hukum Kebebasan Beragamal Berkeyakinan, 1(1): 14.

Schirrmacher, Thomas. (2013). "Religious freedom in Indonesia", International Journal for Religious Freedom, 6(1/2): 90.

Siti Aminah. (2011). "Kasus Ahmadiyah dalam Perspektif Keadilan Sosial", Jurnal Keadilan Sosial, 2(1): 52.

Soetandyo Wignjosoebroto. (2010). "Rule of Law; Suatu Perbincangan di Seputar Masalah Kesamaan Akses untuk Memperoleh Keadilan Khususnya Menyangkut Kepentingan Kaum Miskin", Jurnal Keadilan Sosial, 1(1): 6.

\section{Other Sources:}

Khristofel Anggung Praing. (2014). Penganut Marapu Berjuang Agar Kepercayaan Mereka di Akui. Available from: http://indonesia.ucanews. com/2014/03/19/penganut-marapuberjuang-agar-kepercayaan-merekadiakui// [Accessed August 22, 2014].

M. Amin Abdullah, Kebebasan Beragama atau Berkeyakinan dalam Perspektif Kemanusiaan Universal, AgamaAgama dan Keindonesiaan. (Paper). Presented in forum Advanced Human Rights Training for Lecturers of Law and Human Rights by the Human Rights Study Center, Islamic University of Indonesia (PUSHAM-UII) and 
Norwegian Centre for Human Rights (NCHR) University of Oslo Norway, Djogjakarta Plaza Hotel, Yogyakarta, June 10, 2011.

Siti Musdah Mulia. (2007). Hak Asasi Manusia dan Kebebasan Beragama. (Paper). Available from: http://www. elsam.or.id/downloads/1363164069 HAM dan Kebebasan Beragama.
Musdah Mulia.pdf [Accessed August 6, 2014].

Vivanews. (2014). Soal Agama Baha'i Mendagri Tunggu Keputusan Kemenag. Available from: http://nasional.news. viva.co.id/news/read/524617-soalagama-baha-i--mendagri-tunggukeputusan-kemenag [Accessed October 2, 2014]. 